\title{
Poesía, paisaje, amistad
}

\author{
Francine Masiello \\ University of California, Berkeley
}

En octubre del año pasado realicé un viaje a algunos de los parques nacionales de Estados Unidos -entre ellos, el Gran Cañón- para disfrutar de las gargantas de piedra roja que pertenecen al río Colorado. Tierra de Dios, por cierto. El esplendor de Estados Unidos. Al contemplar su gran belleza, no pude evitar un pensamiento respecto de nuestro quehacer en el campo de la lengua, y más específico aún, en el campo de la poesía. Entre la piedra y la palabra, entonces, quisiera destacar un tema. Permítanme, entonces, estas palabras para llegar eventualmente a honrar a nuestra amiga: la entrañable Gwen Kirkpatrick.

Con el paisaje natural por delante, enfrentamos el tiempo. Los tiempos, mejor dicho; el uno sobrepuesto al otro. La piedra inscripta, rastreada por las estrías de arena sedimentada. Allí se encuentran los fósiles milenarios, pequeños recuerdos de los monstruos submarinos que ahora carecen de nombre. Las grandes gorjas armadas por el hielo y el viento. Al lado de ellas, los surcos de limo; lo que alguna vez fue el piso de un mar antiguo, está hoy a tres mil metros de altura. También vi esta piedra roja al norte de Humahuaca, un pueblito que está en la ruta del Inca, camino entre la Argentina y Perú. Trazos gemelos entre las Américas; el uno llama al otro en su deseo de mutuo reconocimiento. Somos iguales, parecen decir; somos hijos mellizos de la misma pachamama, del mismo viento y respiración que producen piedra y voz. Diana Bellessi había escrito acerca de este encuentro panamericano en su gran y mítico libro de poemas llamado Sur. "¿Será Sur el continente entero?", nos pregunta Diana al explorar las continuidades terrenales que nos conectan desde Ácoma (en Nuevo México) hasta Tierra del Fuego. El círculo, la continuidad, el nexo entre todos y todas: aunque a veces pareciera que un corte en horizontal -entre el norte y el sur- nos separara en el campo de las políticas nacionales y en la naturaleza que nos une.

Pero quiero volver al tiempo. Tierra y temporalidades. Al ver las estrías de la tierra, una capa encima de la otra, estamos presenciando la coexistencia de los tiempos en un solo espacio. Es curiosa esta vuelta. Porque solemos pensar el tiempo en oposición al espacio; aquí sin embargo el espacio devela una realidad temporal -los dos viajan juntos, uno como comprobante del otro-. Ha sido un problema para los filósofos y los geólogos simultáneamente: piensen en la dupla, Darwin y Renan. Darwin enfrentaba ese cuadro durante su viaje a Sudamérica cuando trataba de discernir, a partir de los fósiles, los múltiples tiempos acumulados en la gran Patagonia. Y en casi los mismos años, los filólogos se ocupaban de descifrar, a partir de las capas de sonidos, los orígenes de las lenguas. Es decir: mientras Darwin excavaba la tierra, otros como Ernst Renan excavaban las raíces de los idiomas en busca de una fuente primaria. Extrañas compatiblidades en el siglo XIX. La idea nos acompaña todavía. 
Aparte del trabajo de descubrir entre las ruinas los orígenes del lenguaje y del tiempo, el mundo natural es la escenificación de lo sublime americano, el no sé qué, el nescio quid de la grandeza inexplicable, lo que inspira al mismo tiempo el horror y la admiración. Esta ha sido la experiencia de Heredia delante del Teocalli de Cholula, de Neruda frente a Macchu Picchu, de Mistral en la Patagonia, de Juan L Ortiz al lado del río Gualeguay. ¿Qué ocurre aquí? me pregunto. ¿Una repetición del motivo nacionalista o un ejercicio que tiene que ver con el modo de hablar y mirar? ¿Una metáfora que permite montar la historia del lenguaje en un solo instante del poema? En todo caso, hay una lucha con la materia, al intentar dar nombre a la piedra y dar voz a los sonidos ajenos: de poner el ojo y el oído al detalle paisajístico para poder ampliar el idioma y saber de antemano que nunca vamos a alcanzar esa tan deseada equivalencia entre objeto y vocablo. El recién fallecido Hugo Padeletti tenía alta conciencia de estos cruces y la vemos en su monumental obra llamada, justamente, La atención. Poner atención al detalle de la naturaleza para poder capturar la escena, y quedar en fin en la quietud meditativa sin necesidad de resolver las fuerzas contradictorias que se anidan en nuestra pantalla mental. La imagen de la naturaleza en el poema expresa un deseo de unidad y no de antagonismo. ¿Será, me pregunto, el momento aurático del poema en el que todos los conflictos se reúnen en un solo verso, donde pasado y presente se juntan, donde el detalle mínimo de la naturaleza se entrelaza con el deseo del poeta de abarcar la totalidad?

La poeta argentina Claudia Masin escribe acerca de esta configuración:

El lento suspiro del pasado

Al convertirse en materia,

Súbitamente olvida las palabras

Y su memoria pasa a ser puro espíritu,

Es decir, una piedra.

(Geología 11)

El poema anuncia el fracaso del verbo: para Masin, la palabra es inútil mientras la piedra expresa por sí su relacion con el tiempo y espíritu. Volvamos a otro poema del mismo libro:

De pequeña

probablemente pensara que la geología

era la ciencia que enseñaba a vivir en la tierra.

Geo, tierra, Logía, ciencia. Era razonable,

y desde entonces Yo voy a ser geóloga

cuando sea grande, informaba,

como quien dice voy a averiguar sola

lo que nadie me sabe contar,

voy a clasificar todos los géneros

de dolor que conozco como si fueran piedras.

-Tal vez en los manuales -me decía- 
entre fallas y estalactitas aparezca en una foto

yo con mi disfraz de explorador

y en una nota al pie, esta descripción:

nena de piedra hallada en una cueva

muy al norte, casi escondida,

el cuerpo cubierto de palabras talladas,

por el tiempo transcurrido, incomprensibles (13)

Las metáforas de la tierra y la escritura van tomadas de la mano. Ambas enfocan la fugacidad del sentido, y nuestro deseo de alcanzar entre todos un saber común. Un persistente vaivén entre estasis y movimiento. La fijeza del lugar frente a las líneas de fuga que lo desarman. El trabajo en conjunto, la colectividad, el dos reunido en el uno. La paradoja de la poesía es que logre contener estas antítesis suspendidas en el espacio de la página escrita.

Alicia Genovese, poeta argentina, escribió en un libro reciente sobre las capas de tiempo y espacio que se absorben en la poesía: "Escribir [es] como desplazarse / en el mismo lugar" afirma (La contingencia 40). En su poema "El escritorio, vacío", observa: "Volver a agarrar la zapa, era la expresión de mi madre / cuando había que empezar desde la nada" (82). El gesto remite al "inicio oscuro de los tiempos", agrega Genovese, como si el deseo de cavar las capas de la tierra fuera semejante al deseo del escritor de ordenar papel y verso. Cargar la frase al hombro como si fuera con una pala y, con ella, abrir surcos en la tierra. Retomar el camino escondido y darle nueva vida a la materia que encontramos sobre la ruta. Aquí, tierra y papel encuentran su equivalencia. De la belleza desnuda de la piedra, llegamos a la belleza de la palabra desnuda. Y así ad aeternitatem.

Borges, en uno de sus primeros ensayos críticos, publicado en Cosmópolis, toma una posición contraria. Ve en el paisaje del campo solo la condecoración verbal que otorgamos a la visualidad. Por lo tanto, el "paisaje de campo", dice, "es la mentira" (196). Porque el paisaje es, para Borges, solo sintaxis y metáfora; produce los adverbios que señalan nuestro avance del tiempo.

Este giro señalado por Borges se evidencia en algunos poetas contemporáneos, como en el caso de Mercedes Roffé. En particular su libro, Definiciones mayas (1999), subraya el adverbio temporal como el punto de partida de cada poema. "A veces" y "Entonces" son algunos de los títulos, pero también está el poema "Paisaje", donde el sustantivo sirve de ancla y base de la construcción poética. Cito del final de este poema:

Paisaje del

Pais que lleva adentro

Oh nido pasajero

Pasa seca / muy mayor

Peisaj éxodo / a través de los caminos 
Pisa acción de pisar /\& porción de aceituno o uva que se estruja de una vez en el molino o lagar / zurra o tunda de patadas o coces / Germ. Casa de mujeres públicas; mancebía

Pasaje transición / camino estrecho, oscuro
Peaje precio
Paja
Pija miembro viril / cosa insignificante, nadería

Asia

Paje

Peje pez, pescado / hombre astuto y taimado

Pesa

-Pase

-Pase

(una puerta al vacío)

(19-20).

En este contexto, la naturaleza produce vocabulario, situaciones; despierta diversos saberes, produce relaciones en el tiempo. Finalmente, incita memoria mientras alimenta el deseo de alinear pasado y futuro. Pero más allá de Borges, quien insistía en la gramática que el paisaje pudiera proferir, Mercedes Roffé se refiere también al "país que uno lleva adentro", una fuente de asociaciones libres, capas de sentido que coexisten a partir de la misma escena. Para resumir entonces: la naturaleza produce vocabulario, produce una multiplicidad de tiempos $y$, a la vez, instala una red de contactos que permiten pensar la relación entre el poeta y su público lector.

Los poetas de nuestros días descubren una relación entre paisaje y poesía para hacer prosperar los vínculos afectivos: señalan el contacto entre las voces y los enlaces que se sostienen al interior del poema para vincularse luego con las circunstancias que les rodea. Un ir y venir, un coro de voces: la poesía como ciclo de infinita renovación en el que la sensualidad paisajística será capaz de alterar nuestro entendimiento del momento en que vivimos. Muchos dicen que presenciamos una práctica de la fuga; pero aquí sigo los pasos de Gwen cuando decía que el pasiaje es una práctica en defensa del lugar, en contra de la fuga; facilita la materialidad del encuentro del ser humano con su entorno. El paisaje entonces es un puente sólido entre las topografías del mundo vivido. Afirma, además, nuestro deseo de alcanzar al otro; no de ir en su contra sino de buscar el acompañamiento. De hecho, la poesía que toma por su tema el paisaje y la naturaleza se abre a nuevos caminos: desmitifica la unicidad del poeta como centro del universo discursivo. Anclado en el paisaje, en el espacio, en tierra firme, el poeta se descubre entrelazado en una red de relaciones afectivas y materiales que componen el texto literario. 
Paisaje y afectividad van tomados de la mano. Aquí cito a Diana Bellessi y Úrsula Le Guin, quienes armaron un libro a cuatro manos para festejar el paisaje americano y la amistad que las unía. De su libro Las gemelas (The Twins) de 1986:

Diminutas niñas del sueño

Niñas almas

Plata y turquesa

Niñas tan antiguas.

Una en la proa de un juguete

Alma canoa de los Yurok,

Con cuatro piedras en las esquinas

Del mundo y una en el centro.

Escucha al río

Que susurra a tu cabaña!

Es el frío y dulce Klamath

Que relumbra con salmones, bajo las sequoias,

Norte, norte, la niña llama

$Y$ el bote de sequoia carga

Su pasajera acundando

Mi sueño sobre las aguas

Hondas del Paraná...

Sur, sur, la niña llama

Y la otra también responde (181-83)

El río es el portador de la unidad; vincula el norte y el sur. Más importante aún, el escenario genera -y sostiene- la voz de ambas. Aquí las niñas se llaman la una a la otra; juntan los recuerdos de las escenas paisajísticas para incentivar el acercamiento entre ellas. Al final, del susurro del río, aparece el llamado de la voz.

Esta muestra de amistad frecuentemente emerge del trasfondo de la poesía, más aún de aquella poesía que se ocupa del paisaje. En este sentido, la naturaleza es servicial. Escribe al respecto Gabriela Mistral: "Toda la naturaleza es un anhelo de servicio; sirve la nube, sirve el aire, sirve el surco. Donde haya un árbol que plantar, plántalo tú; donde haya un error que enmendar, enmiéndalo tú; donde haya un esfuerzo que todos esquiven, acéptalo tú" ("El placer de servir"). Mistral propone una entrega al árbol y la tierra. Esta invita nuestra participación, organiza la estrofa poética, plantea un tú como interlocutor para dialogar con la poeta. Sabemos que la amistad 
en poesía es capaz de alterar la forma literaria. Robert Hass en un nuevo libro, A Little Book of Form (2017), señala las maneras en que la amistad altera la forma del poema. Desde los romances medievales, hasta la poesía conversacional, sabemos que el diálogo de a dos exige otra práctica poética:

In this form, twoness cuts both ways. In the fields, the foreman calls out and the crew responds; in a religious ceremony, the celebrant calls out, the community responds. It is a kind of social binding. In a poem it can express splitness or doubleness, and the desire to be whole: two trying to make one (29)

En nuestras tradiciones hispanoamericanas, vemos algo parecido en la ronda donde nace la voz de un "nosotros". Se comparten voz y forma sobre el escenario de la naturaleza. Al igual que Mistral, quien vio en la ronda una manera de compartir con la otra, de extender un puente entre esfera pública y privada sobre el trasfondo del paisaje natural, tenemos el gran momento en que el paisaje se ofrece como la ruta hacia la unión entre poeta y lector.

Y aquí quiero llegar a Gwen Kirkpatrick. No me sorprende que Gwen-la gran lectora del detalle mínimo, la que siempre respeta al otro y la que, en su práctica académica y su trato con la gente, eleva sobre todo el valor de las relaciones humanas- haya escrito sobre el paisaje y los afectos. La suya es la lectura que sana, la que repara, diría Eve Sedgwick. Y en su deseo de escribir críticamente, ella nutre los lazos afectivos de la comunidad intelectual más amplia. En sus ensayos sobre poesía, Gwen destaca su deseo de armar puentes; lo mismo se ve en su búsqueda estética de señalar las continuidades y fijezas frente a la ruptura y el quiebre.

En esta línea, su libro acerca del modernismo y la vanguardia enseña menos las disonancias entre ambos que el bajo continuo que los une (1989). Y en sus estudios concernientes a paisaje, que orientan mis palabras aquí, ella insiste no en la fuga sino en la amena armonía de la totalidad (2008). Será el deseo de completud que la guíe, un deseo de descubrir las bases de contacto presentes en el archivo literario. Aquí una plataforma prestada de la Gwen: se escribe para ocupar el presente, para cimentar las bases de lo moderno sobre la tradición heredada; se cruza el espacio con el tiempo, el ayer con el futuro; se escribe de la naturaleza para llegar a un "nosotros". Entonces, llegamos con ella a proponer que se escribe no para tomar el contrario, sino para descubrir el "con". Rastrea las herencias propias y ajenas respecto de la mirada y el lenguaje. Se deja llevar por los caminos de la inteligencia combinada con la ternura. Deja cantar los bordes entre campo y ciudad. Descubre la unidad perdida por medio del oído y la voz. Efectivamente, entre el sonido de la voz y el paisaje natural, se descubre el lugar donde las amistades se cruzan; y, a la vez, surgen las nuevas modalidades del lenguaje poético que sirven para poder proyectarlos.

Necesito cerrar con referencia a Gabriela Mistral. Muchos (entre ellos Raquel Olea) han señalado la gran importancia de la ronda en la poesía de Mistral: la originalidad de la forma, la urgencia de la voz. Y hasta aquí quiero llegar. En una de las rondas, Mistral escribe: 


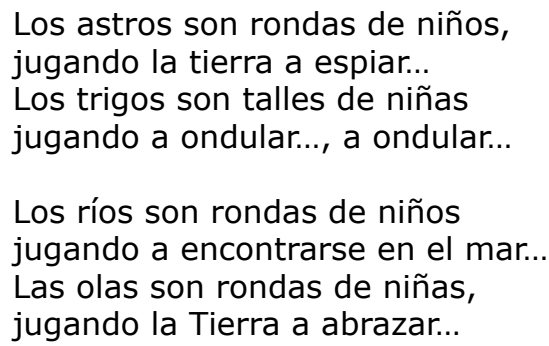

("Todo es ronda")

Me quedo impresionada por el indisoluble vínculo entre paisaje y canción, la naturaleza que forja la voz de las niñas y les permite el encuentro entre ellas. Por alguna razón, la ronda de Gabriela me inspira recuerdos de Gwen sobre todo si pienso en las metas que le han guiado la ética a lo largo de su carrera: el respeto por el trabajo colectivo, el trato delicado con el otro, el amor a la poesía, su fundamental admiración por la naturaleza y su entorno. Gabriela además dejó otra ronda que también me recuerda la Gwen cuando escribía, "Todas íbamos a ser reinas y de verídico, reinar". Pero a diferencia de las mujeres que poblaron el poema de Mistral, sí, Gwen, llegaste a reinar. Sí, Gwen, mi reina, nuestra historia es larga pero feliz, y por detrás, el trasfondo paisajístico que hoy y para siempre nos une.

\section{Obras citadas}

Bellessi, Diana y Ursula K. Le Guin. The Twins, The Dream/ Las gemelas, El sueño. Houston: Arte Público Press, 1996.

Borges, Jorge Luis. "Crítica del paisaje". Cosmópolis 34 (1921): 196.

Genovese, Alicia. La contingencia. Toluca de Lerdo (México): Secretaría de Educación del Gobierno del Estado de México, 2015.

Hass, Robert. A Little Book on Form. An Exploration into the Formal Imagination o Poetry. Nueva York: Harper Collins, 2017.

Kirkpatrick, Gwen. The Dissonant Legacy of Modernismo. Berkeley: University of California Press, 1989.

"The Erasure of form and geography in US and Latin American poetry". Transatlantic Steamer: Vapor Transatlántico, Comp. Miguel Ängel Zapata. Lima, Universidad Nacional de San Marcos/ Hempstead, N.Y: Hofstra University Press, 2008. 17-34.

Masin, Claudia. Geología. Buenos Aires: Nusud, 2001.

Mistral, Gabriela. "El placer de servir" [manuscrito]. Archivo del Escritor. Biblioteca Nacional Digital de Chile. http://www.bibliotecanacionaldigital.cl/bnd/623/w3-article-139303.html .

Olea, Raquel. Como traje de fiesta. Loca Razón en la poesía de Gabriela Mistral. Santiago de Chile: USACH, 2009.

Roffé, Mercedes. Definiciones mayas. Nueva York: Pen Press, 1999.

Sedgwick, Eve Kosofsky. "Paranoid Reading and Reparative Reading". Touching Feeling: Affect, Pedagogy, Performativity. Durham, N.C.: Duke University Press, 2003. 123-201. 